\title{
Pemberdayaan Kelompok Tani Desa Jago dalam Pengolahan Pakan Ternak Berbasis Limbah Pertanian
}

\author{
Nurul Ismillayli, Dhony Hermanto*, Ni Komang Tri Dharmayani dan Surya Hadi
}

Program Studi Kimia, Universitas Mataram, Mataram, Indonesia.

\begin{abstract}
Kata Kunci: Abstrak: Pengembangan peternakan sapi perlu didukung dengan ketersediaan limbah pertanian, fermentasi, pakan ternak, pakan yang berkualitas yang sampai saat ini masih merupakan kendala utama dalam peningkatan produktivitas ternak sapi. Salah satu alternatif penyediaan pakan ternak adalah memanfaatkan dan mengembangkan limbah hasil pertanian dan seperti sekam/jerami/jerami padi yang banyak tersedia di Desa Jago. EM4, Desa Jago Sayangnya bahan pakan jenis ini memiliki kadar protein kasar dan energi rendah dan serat kasar yang tinggi. Oleh karena itu, introduksi teknologi pakan ternak sangat diperlukan untuk meningkatkan nilai gizi pakan sekaligus menjamin ketersediaan pakan sepanjang tahun. Kegiatan pengabdian dengan memberdayakan Kelompok Tani Desa Jago dalam Pengolahan Pakan Ternak Berbasis Limbah Pertanian telah dilakukan. Mitra sasaran adalah anggota kelompok tani Tunas Harapan yang rata-rata merupakan peternak sapi. Kegiatan dilakukan dengan dua tahapan yaitu sosialisasi tentang manfaat limbah peternakan sebagai pakan ternak dan jenis pakan yang bernutrisi tinggi dan kerja praktek pengolahan sekam/jerami padi menjadi pakan ternak. Pembuatan pakan ternak sapi dilakukan melalui fermentasi menggunakan EM4 yang diikuti dengan suplementasi menggunakan rumput laut dan molases untuk meningkatkan protein kasar, karbohidrat dan menurunkan serat kasar sehingga meningkatkan daya cerna dan nutrisi pakan. Anggota kelompok tani Desa Jago merespon positif kegiatan pengolahan pakan ternak sapi dari limbah sekam/jerami padi. Kegiatan ini diharapkan dapat meningkatkan pemanfaatan sekam/jerami padi sebagai limbah pertanian yang melimpah dan menjamin ketersediaan pakan ternak yang murah dan bernutrisi sepanjang tahun.
\end{abstract}

\section{Korespondensi: dhony.hermanto@unram.ac.id}

\section{PENDAHULUAN}

Desa Jago sebagai salah satu desa yang terdapat di Lombok Tengah merupakan desa yang memiliki potensi ternak sapi cukup tinggi yaitu 639 ekor untuk luas wilayah 913 Ha dan 2.821 rumah tangga (BPS Kabupaten Lombok Tengah, 2018). Potensi ini dapat ditingkatkan dengan menjamin ketersediaan pakan ternak yang berkualitas dalam jumlah yang cukup sepanjang tahun. Sementara ini pakan sapi berasal dari padang penggembalaan, rumput alam pada lahan-lahan yang tidak digunakan untuk pertanian yang luasnya ke depan cenderung semakin sempit akibat perubahan fungsi menjadi lahan pemukiman. Hijauan pakan ternak pada musim kemarau juga akan berkurang. Sementara itu, daya beli masyarakat terhadap pakan komersial (konsentrat) yang berkualitas masih rendah akibat sebagian besar bahan 
baku pakan merupakan komoditas impor. Perlu mencari alternatif pakan ternak yang mampu memanfaatkan sumberdaya lokal. Salah satu alternatif pakan ternak adalah dengan memanfaatkan dan mengolah limbah hasil pertanian seperti sekam/jerami padi yang banyak tersedia di Desa Jago. Aktivitas pertanian padi di Desa Jago sangat tinggi, dengan luas tanah sawah 751 Ha dan frekuensi tanam padi 2 kali setahun menyebabkan sekam/jerami padi tersedia sepanjang tahun (BPS Lombok Tengah, 2018).

Sekam/jerami padi mempunyai potensi menjadi bahan pakan karena produksinya tinggi, penggunaannya tidak bersaing dengan kebutuhan manusia, masih belum banyak dipergunakan untuk tujuan-tujuan lain yang lebih bernilai ekonomi sehingga hanya terbuang atau dibakar langsung, keberadaannya terkonsentrasi pada tempat tertentu (di pabrik penggilingan padi) sehingga memudahkan pengumpulannya. Sayangnya bahan pakan jenis ini memiliki kadar protein kasar dan energi rendah dan serat kasar yang tinggi akibat dominasi kandungan lignoselulosa dan silika yang sulit dicerna. Oleh karena itu, introduksi teknologi pakan ternak sangat diperlukan untuk meningkatkan nilai gizi pakan sekaligus menjamin ketersediaan pakan sepanjang tahun. Peningkatan gizi pakan ternak dapat dilakukan melalui fermentasi sekam/jerami padi.

Proses fermentasi dapat meningkatan kualitas pakan sekam/jerami padi dengan meningkatkan kadar protein kasar (Mahendri dkk., 2005; Gunawan dkk, 2013) serta memperbaiki daya cerna pakan. Bioteknologi fermentasi pada prinsipnya dapat menaikkan kualitas bahan berserat tinggi. Salah satu bioteknologi fermentasi yang dapat digunakan ialah bioteknologi "Effective Microorganisms" (EM). Penggunaan EM4 untuk fermentasi jerami padi ini dapat meningkatkan kadar protein dari $1,92 \%$ menjadi $2,67 \%$ atau terjadi kenaikan sebesar 39\%, penurunan serat kasar dari 37,33\% menjadi 13,02\%, dan peningkatan kadar energi dari 302,33 KKal/Kg menjadi 375,62 KKal/Kg. Hasil analisis keragaman menunjukan bahwa fermentasi jerami padi dengan "EM4" menyebabkan terjadi pengayaan nilai nutritif jerami padi (Telew dkk, 2013). Selain itu proses fermentasi jerami jagung dapat menurunkan kandungan residu pestisida golongan organokhlorin (OC) maupun organofosfat (OP), yang mana keberadaan residu pestisida dalam pakan dapat membahayakan kesehatan ternak dan produk ternak yang dihasilkan (Indraningsih dan Sani, 2005).

Inovasi pengolahan sekam/jerami padi menjadi alternatif pakan ini sangat mudah, murah dan ramah lingkungan. Inovasi ini, akan mudah diterima oleh para anggota kelompok tani yang sebagian besar kurang berpendidikan (rata-rata lama sekolah 6,19 tahun pada Tahun 2012) (BPS Kabupaten Lombok Tengah, 2015). Oleh karena itu, kegiatan ini diharapkan dapat meningkatkan pengetahuan anggota kelompok tani dalam mengolah limbah pertania (sekam/jerami padi) sehingga biaya pemenuhan pakan ternak berkurang.

\section{METODE KEGIATAN}

Program ini bekerjasama dengan mitra kelompok tani yang ada di Desa Jago yaitu Kelompok Tani Tunas Harapan, Patuh Angen II dan Timbul Jaya. Peran mitra kelompok tani selain sebagai penerima alih teknologi juga sebagai motor penggerak untuk menyebarkan kegiatan kepada anggota kelompok tani lainnya kegiatan sehingga pemanfaatan limbah pertanian sebagai pakan ternak dapat berkelanjutan. Pada umumnya kelompok-kelompok tani ini sebagian besar menerapkan sistem pertanian terpadu yaitu dalam satu lahan selain 
pertanian juga terdapat peternakan sapi. Sehingga diharapkan dengan transfer ipteks dalam hal teknologi pengolahan pakan dapat mengoptimalkan integrasi sistem pertanian ini.

Tahapan-tahapan yang akan dilakukan dalam melaksanakan solusi yang telah ditawarkan adalah Focus Group Discussion (FGD), sosialisasi dan pelatihan/pendampingan terbagi menjadi 2 bagian, yaitu :

1 .

Focus Group Discussion

(FGD) dan sosialisasi tentang manfaat limbah pertanian (sekam/jerami padi) dan pakan ternak berkualitas.

Dalam tahap ini focus group discussion (FGD) akan dilakukan pengisian kuisioner untuk mengetahui sejauh mana pengetahuan masyarakat tentang manfaat limbah pertanian (sekam/jerami padi) dan pakan ternak berkualitas. Tngkat pengetahuan petani ternak (responden) dilaksanakan tes awal dengan menggunakan daftar pertanyaan (Kuisioner) terdiri dari 10 pertanyaan dengan nilai tertinggi 4 (empat) dan nilai terendah 1 (satu). Dengan kriteria tingkat pengetahuan yang diperoleh masing-masing responden dapat diinterprestasikan sebagai berikut :

Nilai tertinggi (Maksimal) $10 \times 4=40$

Nilai terendah (minimum) $10 \times 1=10$

Oleh karena itu, kriteria tingkat pengetahuan yang diperoleh masing-masing responden dapat dikelompokkan dalam kategori :

a. Baik bila nilai $\geq 31-40$

b. Sedang bila nilai $\geq 21-30$

c. Kurang bila nilai $10-20$

Kegiatan FGD kemudian dilanjutkan dengan sosialisasi sebagai feed back dari hasil FGD. Metode sosialisasi yang digunakan adalah ceramah tentang jenis dan manfaat limbah pertanian dan pakan ternak yang berkualitas. Penyuluhan disertai dengan tayangan visual agar peserta semakin paham. Pada akhir sesi akan diadakan diskusi dan tanya jawab mengenai hal-hal yang belum dipahami oleh peserta. Selain itu para peserta diberi kesempatan untuk melakukan diskusi antar peserta dan pemateri tentang pemahaman materi yang disampaikan

2 .

Tahap praktek untuk mengolah limbah pertanian menjadi produk pakan ternak melalui fermentasi menggunakan EM4. Pada tahap ini dilakukan pola pendampingan dengan mengajarkan teknik pengolahan yang mudah, murah dan ramah lingkungan dengan menggunakan bahan-bahan yang telah disediakan seperti sekam/jerami padi dengan kadar air 10-12\%, molases, EM4, tepung rumput laut dan air. Alat yang dibutuhkan adalah kantong plastik besar, terpal dan ember. Sekam/jerami padi difermentasi selama 7 hari dalam keadaan anaerob (tertutup) dengan tahapan proses sebagai berikut:

a.

Sediakan terpal kemudian letakkan sekam/jerami padi $(100 \mathrm{~kg})$ di atasnya.

b.

Larutkan 2 liter molases dalam 25 liter air dan ditambahkan 1 liter EM4 kemudian diaduk rata.

c.

Larutan molases dan EM4

disiramkan secara merata di atas tumpukan sekam/jerami padi kemudian dimasukkan ke dalam kantong plastik besar dan diikat agar tidak ada udara yang masuk. 
d.

Kantong plastik berisi sekam/jerami padi dapat ditutup terpal untuk melindungi dari sinar matahari atau diletakkan di tempat yang terlindung dari sinar matahari.

e.

Setelah $\quad 7 \quad$ hari

sekam/jerami padi terfermentasi dapat diberikan pada ternak sesuai dengan kebutuhan. Sekam/jerami padi terfermentasi dapat ditambahkan dengan molases dan tepung rumput laut untuk meningkatkan nilai gizi pakan. Sekam/jerami padi terfermentasi sisa ditutup kembali dengan rapat, hindari genangan air dan terik matahari agar tahan hingga 2 bulan.

\section{HASIL DAN PEMBAHASAN}

Kegiatan ini diawali dengan sosialisasi tentang teknologi pengolahan pakan yang berbasis limbah pertanian. Potensi pertanian Desa Jago adalah tanaman pangan khususnya padi sehingga sekam/jerami padi digunakan sebagai bahan baku pakan ternak. Pada kegiatan ini dilakukan FGD dan pengisian kuisioner oleh peserta untuk mengetahui tingkat pengetahuan awal peserta mengenai pengolahan limbah pertanian menjadi pakan dan pakan ternak yang berkualitas. Kegiatan FGD dilanjutkan dengan sosialisasi. Metode sosialisasi yang digunakan adalah ceramah tentang jenis dan manfaat limbah pertanian dan pakan ternak yang berkualitas. Penyuluhan disertai dengan tayangan visual agar peserta semakin paham. Pada akhir sesi akan diadakan diskusi dan tanya jawab mengenai hal-hal yang belum dipahami oleh peserta. Selain itu para peserta diberi kesempatan untuk melakukan diskusi antar peserta dan pemateri tentang pemahaman materi yang disampaikan. Para peserta sangat antusias karena mendapatkan pengetahuan baru untuk mengolah limbah pertanian seperti sekam/jerami padi menjadi pakan ternak sapi.

Kegiatan sosialisasi dilanjutkan dengan kerja praktek pengolahan pakan. Pengolahan pakan ternak diawali dengan fermentasi sekam/jerami padi secara biologi menggunakan EM4 dan molases. Pakan yang akan diawetkan diproses dari bahan baku berupa sekam/jerami padi dengan kadar air berkisar antara 10-12\%, kemudian dimasukan dalam kantong plastik kedap udara. Proses fermentasi dilakukan di tempat teduh (terlindungi dari sinar matahari) dalam waktu 7 hari. Hasil fermentasi sekam/jerami padi yang baik ditandai dengan ciri-ciri bau sekam/jerami harum, tekstur lebih lemas dibanding tekstur awal dan tidak busuk atau berjamur. Kadar air sekam/jerami padi mempengaruhi keberhasilan fermentasi. Bila kadar air terlalu tinggi makan sekam/jerami padi akan busuk atau berjamur. Oleh karenanya pada kegiatan ini digunakan sekam/jerami padi dengan kadar air kira-kaira $10-12 \%$. Bila kadar air lebih tinggi maka volume air untuk mengencerkan molases dan EM4 dikurangi. Selain itu suhu fermentasi juga berpengaruh. Kondisi pertumbuhan ideal bagi mikroba terjadi pada suhu $35^{\circ}$ sampai $45^{\circ} \mathrm{C}$ oleh sebab itu bila suhu sudah naik mendekati $50^{\circ} \mathrm{C}$ adonan perlu dibongkar dengan maksud mempertahankan suhu ideal.

Larutan EM4 merupakan suatu kultur campuran berbagai mikroorganisme yang bermanfaat terutama Lactobacillus, bakteri fotosintetik, actynomycetes, ragi dan jamur fermentasi (Telew dkk, 2013). Mikrorganisme ini akan membuka lapisan lignoselulosa dan memecah karbohidrat kompleks menjadi lebih sederhana sehingga sekam/jerami padi lebih mudah dicerna oleh sapi. Selain itu fermentasi sekam/jerami padi dapat meningkatkan protein pakan dengan adanya protein sel tunggal yang berasal dari multiplikasi biomassa sel 
mikroorganisme pada larutan EM4. Proses fermentasi dilanjutkan dengan suplementasi pakan dengan menambahkan sekam/jerami padi terfermentasi dengan molases dan tepung rumpuk laut. Kegiatan sosialisasi dan kerja praktek pengolahan limbah sekam/jerami padi menjadi pakan sapi terdapat pada Gambar 1.

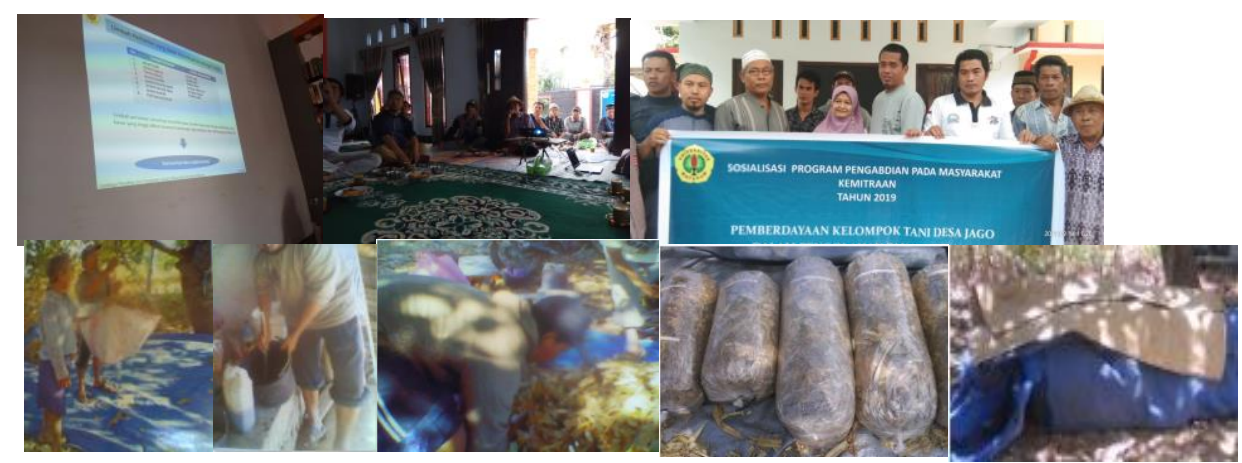

Gambar 1. Sosialisasi dan praktek kerja pengolahan pakan ternak berbasis limbah pertanian

Kegiatan kerja praktek kemudian dilanjutkan dengan pengisian kuisioner untuk mengukur tingkat pemahaman dan pengingkatan pengetahuan peserta setelah diberikan pengetahuan dan keterampilan tentang pengolahan limbah sekam/jerami padi menjadi pakan ternak. Peningkatan pengetahuan ditampilakan secara kuantitatif pada Gambar 2. Terjadi peningkatan pengetahuan peserta mengenai pengolahan pakan ternak berbasis limbah pertanian yang ditandai dengan meningkatnya persentase responden berkriteria pemahaman baik dan sedang dan menurunnya persentase responden yang berkriteria pemahaman kurang.

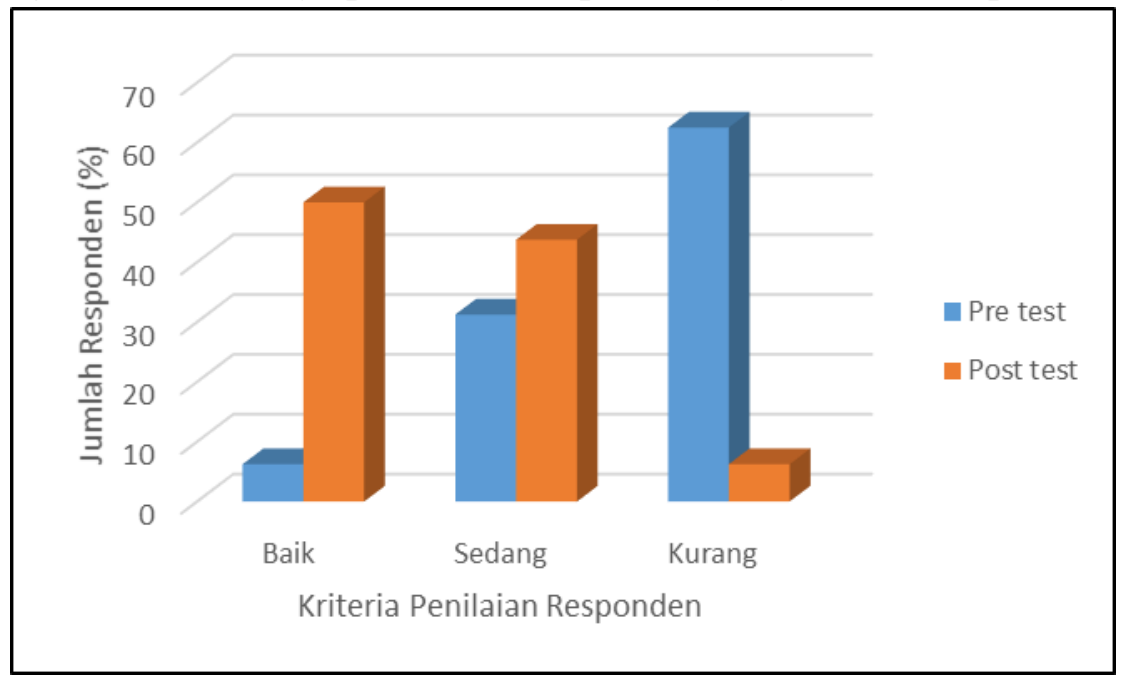

Gambar 2 Grafik perbandingan tingkat pemahaman peserta tentang pengolahan pakan ternak

\section{KESIMPULAN DAN SARAN}

Kegiatan pengabdian berupa sosialisasi dan praktek kerja meningkatkan pengetahuan dan keterampilan kelompok-kelompok tani di Desa Jago tentang teknologi pengolahan pakan ternak sapi yang berbasis limbah pertanian. Fermentasi dan suplementasi sekam/jerami padi dapat meningkatkan kualitas dan daya simpan sekam/jerami padi sehingga diharapkan dapat menjadi pakan alternatif yang dapat tersedia sepanjang tahun. 


\section{UCAPAN TERIMA KASIH}

Penulis mengucapkan terima kasih kepada Universitas Mataram yang telah memberi dukungan financial terhadap pengabdian ini melalui skim pengabdian PNBP Tahun Pelaksanaan 2019 dan Kolompok Tani Tunas Harapan, Patuh Angen II dan Timbul Maju atas partisipasinya pada kegiatan pengabdian.

\section{DAFTAR PUSTAKA}

Badan Pusat Statistik Kabupaten Lombok Tengah, 2015, Statistik Daerah Praya 2015, diakses dari http://lomboktengahkab.go.id pada Tanggal 25 Mei 2016.

Badan Pusat Statistik Kabupaten Lombok Tengah, 2018, Kecamatan Praya dalam Angka 2018, diakses dari http://lomboktengahkab.go.id/ publication/download.html pada Tanggal 10 Mei 2019.

Gunawan, E.R., Suhendra, D., Hermanto, D., 2013, Optimalisasi Integrasi Sapi, Jagung, Dan Rumput Laut (Pijar) Pada Teknologi Pengolahan Pakan Ternak Berbasis Limbah Pertanian Jagung - Rumput Laut Guna Mendukung Program Bumi Sejuta Sapi (Bss) Di Nusa Tenggara Barat, Buletin Peternakan, Vol.37, No. 3, 157-164. DOI: 10.21059/buletinpeternak.v37i3.3086.

Indraningsih dan Sani, Y., 2005, Kajian kontaminasi pestisida pada limbah padi sebagai pakan ternak dan alternatif penanggulangannya. Pros. Seminar Nasional Pengembangan Usaha Peternakan Berdaya Saing di Lahan Kering. Puslitbang Peternakan- UGM. Yogyakarta:108-119.

Mahendri, I.G.A.P., B. Haryanto, E. Handiwirawan, A. Priyanti, L. Natalia, Indraningsih dan R.A. Saptati, 2005. Laporan Inovasi Teknologi Pakan Padi Fermentasi dengan Probion untuk Meningkatkan Kinerja Produksi Ternak Ruminansia. Puslitbang Peternakan.

Telew, C., Kereh, V.G, Untu, I.M dan Rembet, B.W., 2013, Pengayaan Nilai Nutritif Sekam/jerami Padi Berbasis Bioteknologi "Effective Microorganisms" (EM4) Sebagai Bahan Pakan Organik, Jurnal Zoot, Vol.32 No. 5, 1-8. 